\title{
Fluvial Record of Late Pleistocene and Holocene Geomorphic Change in Northern Tunisia - Global, Regional or Local Climatic Causes?
}

\author{
D. Faust ${ }^{1}$, C. Zielhofer ${ }^{1}$, F. Diaz del 0lmo and R. B. Escudero ${ }^{2}$ \\ ${ }^{1}$ Dept. of Physical Geography, Dresden University of Technology, 01062 Dresden, Germany; dominik.faust@mailbox.tu-dresden.de \\ 2Dept. of Physical Geography, University of Seville, 41004 Seville, Spain; baena@us.es
}

Geomorphical-sedimentological approaches with high-resolution stratigraphic records round out Quaternary paleoclimatic and paleo-process research. Our investigations focus on Late Pleistocene and Holocene floodplain evolution.

The central Medjerda Valley, Northern Tunisia (Fig. 1) is a tectonic depression zone that has its origin in the orogenesis of the Atlas Mountains. An up to $10 \mathrm{~km}$ wide floodplain has been incised into it by the meandering Medjerda River. The floodplain is filled with Quaternary sediments, the latest of which are of Late Pleistocene and Holocene age. The floodplain sedimentation allowed the development of predominantly horizontal, well-stratified layer sequences, interrupted by soil-forming processes (Fig. 1).

\section{Methodology}

From 1999 to 2002, fieldwork led to the selection and sampling of more than 20 representative key profiles. Field observations and pedological analyses (granulometry, organic matter, $\mathrm{CaCO}_{3}$ content of clay and silt fraction, heavy minerals, thin section analyses) allow us to distinguish five main stratigraphical series. About 60 AMS radiocarbon samples establish a late Quaternary chronology. In several cases, charcoal pieces are remnants of firesites and cultural layers, so we assume we have dated in situ material.

In our investigation, magnetic intensity $\left[\mathrm{mA} \mathrm{m}^{-1}\right]$ and magnetic susceptibility $\left[K_{o}=10^{-6}\right.$ SI units], as well as inclination and declination $\left[{ }^{\circ}\right]$, were recorded. Because of significant similarity with secular variation curves from Sicily (Tanguy et al., 2003), our declination and inclination values give major chronological information about floodplain evolution.

On the basis of chronological findings (paleomagnetics, ${ }^{14} \mathrm{C}$ data,

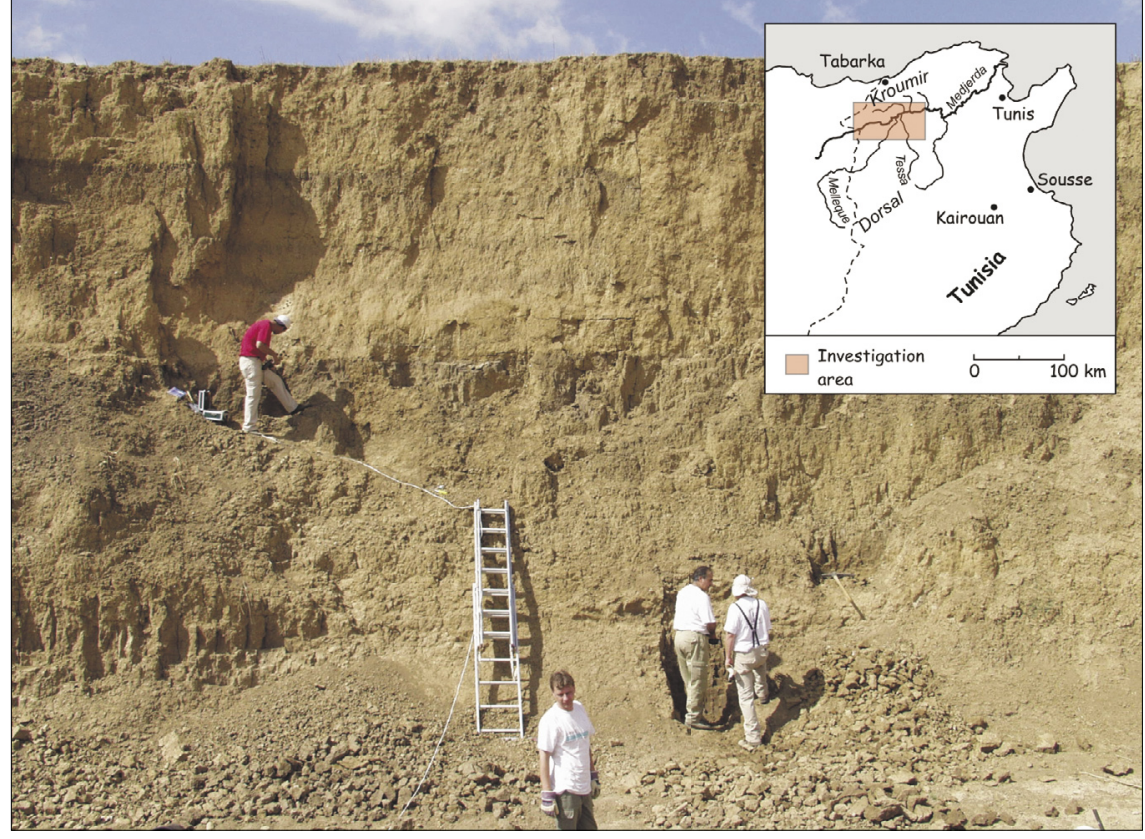

Fig. 1: Area of investigation; excellent exposure conditions allowed detailed sampling

artifacts) and the corresponding sediment thickness of the layers, we can reconstruct a curve for average sedimentation rate. In doing so, the sedimentary conditions between two chronologically well-known marks are regarded as homogeneous. Records of sedimentation rates give detailed information about late Pleistocene and Holocene alluvial history.

\section{Results}

Detailed morphostratigraphical fieldwork, paleomagnetics and radiocarbon dates provide a centennial-scale record of Northern Tunisian fluvial sequences (Fig. 2). Alternating sediment texture, sedimentation rates and soil formation within Medjerda overbank deposits indicate short-term fluctuations in late Pleistocene and Holocene fluvial dynamics. Mediterranean river systems show a direct reaction to climatic shifts even of short duration.

Stratigraphically, the base of the synthetic profile is composed of a well-developed, rubefied soil. This soil is formed in a floodplain sediment in which interbedded mollusces give a radiocarbon age of approx. $42.8 \mathrm{ky}$ (uncal). The red soil is covered by fine sedimentation (silty-clayey) at about $13.5 \mathrm{ky}$ cal BP. This sedimentation continues until 12.6 ky cal BP, under climatic conditions similar to modern times (macroremnants of a dated firesite). According to our datings, the Younger Dryas begins at 12.4 ky cal BP and ends about $11.8 \mathrm{ky}$ cal BP. During the Younger Dryas, coarse sediments and gravels were deposited. The onset of the Holocene (11.8 ky cal BP) is marked by fine sedimentation lasting until $6.6 \mathrm{ky}$ cal BP. This is a long period of geomorphic stability, even if sedimentation seems to accelerate at about $8.2 \mathrm{ky}$ cal BP, indicated by the paleomagnetic records of some profiles. At $6.6 \mathrm{ky}$ cal BP, the stable period is interrupted by sedimentation of coarse material. The period that follows is characterized by fine sedimentation in most parts of the floodplain in which a distinct soil is formed (Mid-Holocene Stability).

Around 4.8 ka cal BP, poorly sorted sediments cover the mid- 


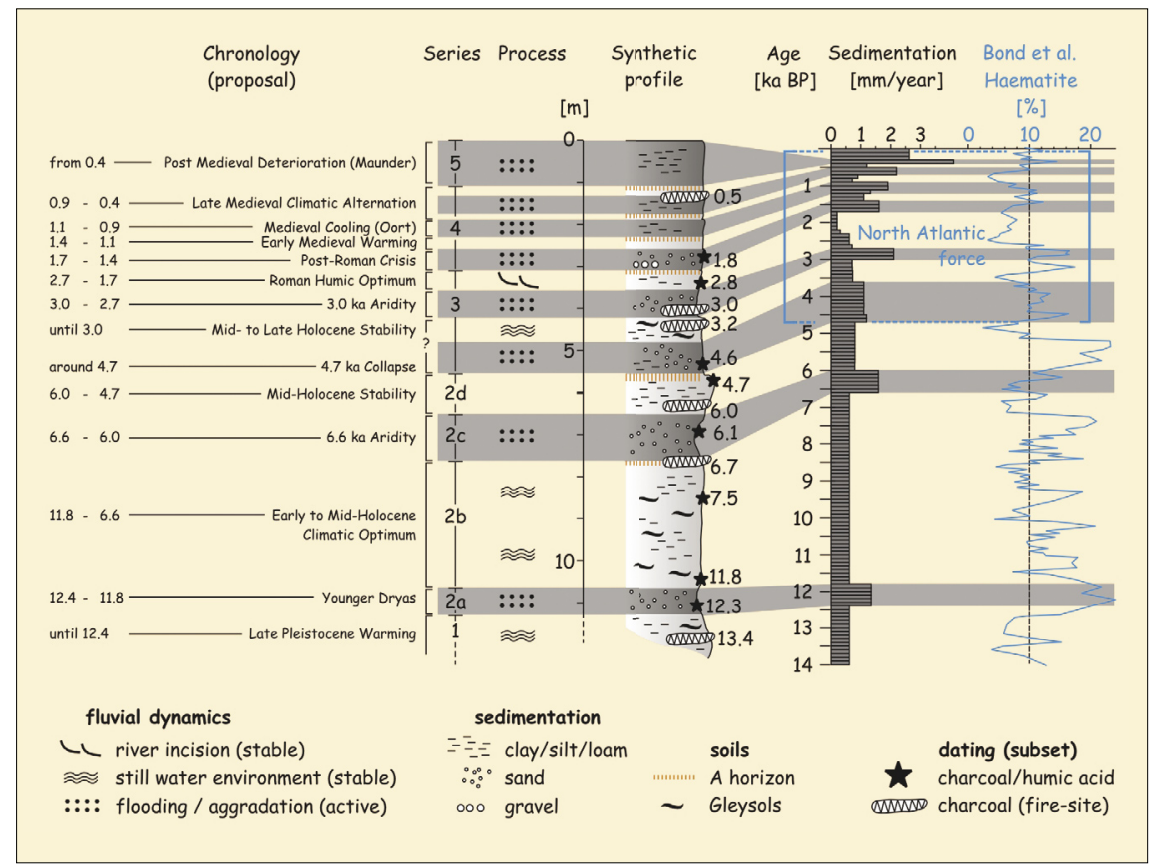

Fig. 2: Synthetic profile of the Medjerda Valley, Northern Tunisia. Chronostratigraphy is based on the analyses of 20 key profiles.

Holocene soil. This indicates an enhancement of morphodynamic processes. Sediments then fineup until Punic times. After $3.0 \mathrm{ka}$ cal BP, increased morphodynamic processes take place for a short time (dating of two firesites in one exposure). This aggradation of sandy deposits ends about 2.7 ka cal BP. About 2.0 ka cal BP, morphodynamic stability and soil formation may be observed, although the timing of the beginning of soil formation is still unknown. At 1.7 ka cal BP, an accentuated restart of fluvial dynamics takes place. At this time, the morphodynamically stable Punic-Roman period ends and most of the soils are buried under coarse sediments (Post Roman Crisis). Certain sediment strata with ages between 1.2 and $0.8 \mathrm{ka}$ cal BP show humic enrichment due to soil formation. Subsequent minor flooding yields only fine sediments. The top of this sediment-sequence also shows a slight humification. At $0.4 \mathrm{ka}$ cal BP (dating of a firesite), devastating floods occur in the entire Medjerda Basin, leaving thick laminated sediments, referred to as the Youngest Layer.

\section{Conclusions}

The Medjerda river system within the semi-arid to sub-humid subtropics of Mediterranean North Tunisia c) Medjerda overbank sediments document increased fluvial activity around 6.6 to $6.0 \mathrm{ka}$. The 6.6 ka event is not well described in other paleoclimatic records. This indicates the possibility of major changes in aridification, even at a regional to local scale.

d) The comparison of mid- to late Holocene sedimentation rates of the Medjerda with the Haematite curve of Bond et al. (2001) reveals a parallel progression of late Holocene North Atlantic coolings and increased alluviation in Mediterranean Tunisia. Short-term periods of geomorphic activity in Northern Tunisia match well with North Atlantic Bond events. The findings indicate a climatic link from the $4.7 \mathrm{ka}$ collapse until today. During the last 2,000 years, climatic optima caused landscape stability regardless of the land-use intensity (Faust et al. 2004). Our findings provide evidence that late Holocene fluvial dynamics in Northern Tunisia were chiefly driven by climate. Anthropogenic impact at most intensified or attenuated the geomorphic processes.

a) Changes in fluvial dynamics during the late Pleistocene to early Holocene can be assigned to global climatic shifts. Climate changes due to shifts in the North Atlantic deep water formation also seem to be reflected in the central Mediterranean region. However, the paleogeomorphological response of the Younger Dryas appears to be significantly shorter.

b) In the course of the early to mid-Holocene, major shifts in the Medjerda fluvial dynamics correlate with changes in Saharan climate. Brief Saharan aridification around $5 \mathrm{ka}$ corresponds with the 4.7 ka collapse within the Medjerda River system. In contrast, the worldwide documented 8.2 ka EMTH event cannot clearly be deduced from the Medjerda overbank deposits.

\section{Acknowledgements}

We would like to thank the Deutsche Forschungsgemeinschaft (DFG) for supporting this project (FA 239/2-1 and FA 239/2-2).

\section{REFERENCES}

Bond, G.C., Kromer, B., Beer, J., Muscheler, R., Evans, M.N., Showers, W., Hoffmann, S., Lotti-Bond, R. Haidas I. AND Bonani, G., 2001: Persistent solar influence on north Atlantic climate during the Holocene. Science, 294: 2130-2136.

Faust, D., Zielhofer, C., Baena, R. and Diaz del Olmo, F., 2004: High resolution fluvial record of late Holocene geomorphic change in northern Tunisia: climatic or human impact? Quaternary Science Reviews, 23(16-17): 1757-1775.

RohDENBURG, H., 1983: Beiträge zur allgemeinen Geomorphologie der Tropen und Subtropen. Geomorphodynamik und Vegetation - Klimazyklische Sedimentation - Panplan/Pediplain-Pediment-Terrassentreppen. Catena, 10: 393-438.

Tanguy, J.-C., Le Goff, M., Principe, C., Arrighi, S., Chillemi, V., Paiotti, A., La Delfa, S. and Patanè, G., 2003 Archeomagnetic dating of the Mediterranean volcanics of the last 2100 years: validity and limits. Earth and Planetary Science Letters, 211: 111-124. 